\title{
Do patients with moderately impaired gastrointestinal function requiring enteral nutrition need a predigested nitrogen source? A prospective crossover controlled clinical trial
}

\author{
R G P Rees, W R Hare, G K Grimble, P G Frost, D B A Silk
}

\begin{abstract}
This prospective double blind randomised seven day crossover controlled clinical trial was carried out to determine whether enterally fed patients with moderately impaired gastrointestinal function require a predigested nitrogen $(\mathbf{N})$ source compared with whole protein. Twelve malnourished patients with varying gastrointestinal abnormalities, who required enteral feeding, received $2 \cdot 251$ of one of two isocaloric isonitrogenous enteral diets (1 kcal $/ \mathrm{ml}, 4.8 \mathrm{~g}$ nitrogen $/ \mathrm{l})$ containing either predominantly medium chain peptides (tetra or higher peptides) or whole protein as the nitrogen source. Nitrogen absorption and balance were calculated from dietary intake and analysis of $\mathbf{2 4}$ hour total urinary and faecal nitrogen for the last five days of each study period. There was no significant difference in either stool weight (110 (SEM) (49) $v 111$ (32) g/d), nitrogen absorption (91 (2) $v 89(2) \%$ ) or nitrogen balance $(+1.0(1.3) v+0.6(1.4) \mathrm{g}$ nitrogen/d) between the peptide and whole protein nitrogen sources when all patients are considered. There was, however, evidence to suggest a nutritional advantage from administering an enteral diet whose nitrogen source comprises oligopeptides, rather than whole protein, to a subgroup of patients with small bowel disease.
\end{abstract}

Enteral nutrition has become an accepted method of providing nutritional support to malnourished patients with a functioning gastrointestinal tract. The most widely used administration technique is 24 hour infusion of a formulated enteral diet, with or without the use of a peristaltic pump, through a nasal fine bore feeding tube positioned in the stomach or upper small intestine. ${ }^{1}$

One of the aims of nutritional support is to place patients in positive nitrogen balance. Attention has, therefore, been recently focused on the qualitative and quantitative characteristics of the nitrogen source of enteral diets. In patients with normal, or near normal, gastrointestinal function, there is no justification for prescribing enteral diets with other than a whole protein based nitrogen source, ${ }^{2}$ moreover, it is the quantity of whole protein prescribed which most commonly determines whether positive nitrogen balance is achieved. ${ }^{3}$ In patients with severely impaired gastrointestinal function, however, such as those with the nutritionally inadequate short bowel syndrome or severe exocrine pancreatic insufficiency caused by cystic fibrosis, it is clear that nitrogen should be administered in a predigested form to ensure its maximum absorption. ${ }^{4}$ Results from intestinal perfusion studies that have consistently shown more efficient absorption of $\alpha$-amino nitrogen from partial hydrolysates of whole protein than equivalent free amino acid mixtures, suggest that there are theoretical reasons for prescribing predigested diets based on the use of small peptides.'

It remains unclear, however, as to what form of nitrogen should be administered to a third and frequently encountered group of patients namely, those with less extensive surgery, or disease of the gastrointestinal tract but who may have impaired assimilatory function. This would include patients with partial gastrectomy, small bowel resection or disease, feeding jejunostomy and resolving pancreatitis or pancreatic resection.

As it is seldom feasible to determine the degree of gastrointestinal function in this type of patient before feeding is instituted, decisions about what type of nitrogen source should be prescribed are based on the prescriber's perception of the assimilatory capacity of that individual patient for whole protein. Data derived from a recently published United Kingdom nutrition survey indicate that a substantial body of clinical opinion largely favours the prescribing of enteral diets with a predigested nitrogen source for patients with moderately impaired gastrointestinal function. ${ }^{\prime}$ Given the unsatisfactory nature of such decision making, with its attendant cost implications, the present double blind crossover controlled clinical trial was undertaken to determine whether patients assessed as having moderately impaired gastrointestinal function, and requiring nutritional support, should be prescribed an enteral diet whose nitrogen source is based on whole protein or small peptides.

\section{Methods}

PATIENTS

Twelve postoperative or acutely ill patients (eight male, median age 61 years), who required enteral nutrition as the only means of nutritional intake and who in the clinical opinion of the primary care physician and nutritional support team, were likely to have moderately impaired gastrointestinal function, were included in the study. None had hepatic or renal insufficiency, diabetes mellitus, or were restricted to less than 
TABLE I Details of patients studied and nutritional status at randomisation

\begin{tabular}{|c|c|c|c|c|c|c|c|c|}
\hline Patient & Age & Sex & $\begin{array}{l}\text { Actual } \\
W t(\mathrm{~kg})\end{array}$ & $B M I^{\star}$ & $\begin{array}{l}\text { Plasma } \\
\text { albumin } \\
(\mathrm{g} / \mathrm{l})\end{array}$ & $\begin{array}{l}T S F \\
(\mathrm{~mm}) t\end{array}$ & $\begin{array}{l}M A C \\
(\mathrm{~cm}) \ddagger\end{array}$ & Clin diagnosis \\
\hline 1 & 62 & $\mathrm{~F}$ & 72 & $25 \cdot 8$ & 19 & $11 \cdot 2$ & $18 \cdot 2$ & Resolved pancreatitis \\
\hline 2 & 73 & $M$ & 64 & $19 \cdot 7$ & 39 & $8 \cdot 4$ & $19 \cdot 1$ & $\begin{array}{l}\text { Resolved pancreatitis, Polya } \\
\text { gastrectomy }(10 \mathrm{yr})\end{array}$ \\
\hline 3 & 56 & M & 47 & $15 \cdot 3$ & 25 & $4 \cdot 0$ & $18 \cdot 0$ & $\begin{array}{l}\text { Post pancreaticoduodenectomy } \\
\text { (Whipple's), Polya } \\
\text { gastrectomy (26 yr) }\end{array}$ \\
\hline 4 & 81 & $M$ & 46 & $15 \cdot 0$ & 25 & $4 \cdot 6$ & $18 \cdot 8$ & $\begin{array}{l}\text { Laparotomy for adhesions, } \\
\text { Polya gastrectomy }(20 \mathrm{yr})\end{array}$ \\
\hline 5 & 59 & $\mathrm{~F}$ & 40 & $15 \cdot 6$ & 38 & $5 \cdot 8$ & $19 \cdot 6$ & $\begin{array}{l}\text { Pneumonia, Biliroth I } \\
\text { gastrectomy }(12 \mathrm{yr})\end{array}$ \\
\hline 6 & 15 & M & 62 & $20 \cdot 3$ & 29 & $7 \cdot 6$ & $22 \cdot 0$ & $\begin{array}{l}\text { Feeding jejunostomy after } \\
\text { trauma to duodenum }\end{array}$ \\
\hline 7 & 76 & $\mathrm{~F}$ & 46 & $16 \cdot 5$ & 30 & $6 \cdot 2$ & $24 \cdot 6$ & $\begin{array}{l}\text { Feeding jejunostomy after } \\
\text { drainage of periduodenal } \\
\text { abscess }\end{array}$ \\
\hline 8 & 77 & $M$ & 43 & $14 \cdot 5$ & 28 & $2 \cdot 4$ & $17 \cdot 4$ & $\begin{array}{l}\text { High output ileostomy after } \\
\text { proctocolectomy for ulcerative } \\
\text { colitis }\end{array}$ \\
\hline 9 & 64 & M & 43 & $14 \cdot 0$ & 21 & $3 \cdot 2$ & $17 \cdot 0$ & Jejunal diverticulosis \\
\hline 10 & 61 & $\mathbf{F}$ & 44 & $16 \cdot 2$ & 22 & $7 \cdot 0$ & $18 \cdot 1$ & $\begin{array}{l}\text { Gastrointestinal amyloidosis } \\
\text { secondary to multiple } \\
\text { myeloma }\end{array}$ \\
\hline 11 & 47 & $M$ & 60 & $19 \cdot 2$ & 26 & $4 \cdot 0$ & $24 \cdot 1$ & $\begin{array}{l}\text { Ileocolonic Crohn's disease ( } 11 \\
\text { yr), terminal ileal resection } \\
\text { and right hemicolectomy ( } 10 \\
\text { yr) }\end{array}$ \\
\hline 12 & 35 & $M$ & 42 & $14 \cdot 1$ & 28 & $5 \cdot 6$ & $20 \cdot 2$ & $\begin{array}{l}\text { Terminal colostomy and mucus } \\
\text { fistula, ileocolonic Crohn's } \\
\text { disease }(15 \mathrm{yr}) \text { with terminal } \\
\text { ileal resection }(5 \mathrm{yr})\end{array}$ \\
\hline
\end{tabular}

$\star$ Body mass index $\left(\mathrm{Wt} / \mathrm{Ht}^{2}\right)<20=$ significantly malnourished

†Triceps skinfold thickness (men 7.5-11.3 mm, women 9.9-14.9 mm $(60-90 \%$ adult reference standard values)

$\ddagger$ Midarm circumference (men $17 \cdot 6-26 \cdot 3 \mathrm{~cm}$, women $17 \cdot 1-25 \cdot 7 \mathrm{~cm}(60-90 \%$ adult reference standard values)

21 of fluid daily. Details of patients studied and their nutritional status are given in Table I. Anthropometric assessment included measurement of weight, height, triceps skinfold thickness and midarm circumference. ${ }^{6}$ Plasma albumin was measured using a standard dye binding technique. Most patients were significantly malnourished. Patient 1, although not clinically wasted at the time of feeding, was persistently anorexic and had a very low plasma albumin level.

The first two patients, one of whom had previously had a partial gastrectomy, were in the early stages of recovery after acute pancreatitis. A further patient (patient 3 ) had had a subtotal pancreatectomy for carcinoma. He had not been prescribed oral pancreatic enzyme supplements when referred to our unit and had previously had a partial gastrectomy for peptic ulcer disease. Patients 4 and 5 also had a history of partial gastrectomy. Patients 6 and 7 required enteral nutrition through a surgically fashioned jejunostomy, through which was inserted a feeding catheter. Patient 8 had a high output ileostomy

TABLE II Composition of diets $(\text { per } 2 \cdot 25 l)^{\star}$

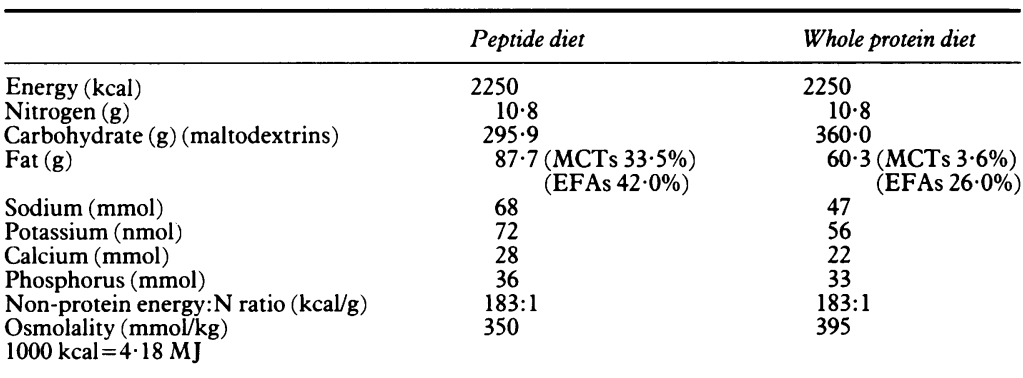

^According to manufacturers' data. after total colectomy for ulcerative colitis three months previously. Ileostomy effluent volumes averaged $>1 \cdot 31 / \mathrm{d}$ with biochemical steatorrhoea (52 mmol fatty acid/d) while on a ward diet. Patient 9 had extensive jejunal diverticular disease with a positive breath hydrogen test. ${ }^{\text {? }}$ He was not receiving oral antibiotics and had steatorrhoea ( $48 \mathrm{mmol}$ fatty acid/d) on a standard $100 \mathrm{~g}$ fat diet. Patient 10 had steatorrhoea secondary to amyloid infiltration of the small bowel mucosa associated with multiple myeloma. The final two patients had been admitted with exacerbations of longstanding ileocolonic Crohn's disease. Both had previously undergone ileal resection $(100-200 \mathrm{~cm})$ and patient 12 currently had a colostomy for colonovesicular fistular disease.

\section{EXPERIMENTAL DESIGN AND MATERIALS}

Patients were randomised to receive 2.251 of either a predigested enteral diet or an equinitrogenous and equicaloric quantity of polymeric diet in a seven day double blind crossover study. The predigested diet (Reabilan, Laboratories Sopharga, Puteaux, France) contained a milk protein derived oligopeptide nitrogen source prepared by the action of trypsin and chymotrypsin on whey proteins (one third) and casein (one third) using an industrial continuous enzymic membrane reactor technique at $38^{\circ} \mathrm{C}$. The remaining one third was composed of a mixture of non-phosphorylated peptides extracted from the casein hydrolysate. The nonprotein energy source of the predigested diet comprised glucose polymers $(60.3 \%)$, medium chain triglycerides $(15 \cdot 8 \%)$, essential fatty acids $(14 \cdot 3 \%)$, and long chain triglycerides $(9 \cdot 6 \%)$ The polymeric enteral diet was prepared in the hospital diet kitchen by adding $112.5 \mathrm{~g}$ Caloreen glucose polymer to $4.5 \times 375 \mathrm{ml}$ cans of Clinifeed 400 (Roussel Laboratories Ltd, Wembley, Middlesex) and making the final volume up to $2 \cdot 251$ with sterile distilled water. Clinifeed 400 is also a whole milk protein containing enteral diet, while glucose polymers and long chain triglycerides constitute the energy sources. The compositions of the two enteral diets are summarised in Table II. Both nitrogen sources consisted of casein and whey proteins, and their respective amino acid compositions would have been very similar and well balanced nutritionally.

The peptide chain length of the partial enzymic hydrolysate of milk proteins was determined using ligand exchange chromatography with $\mathrm{Cu}$ (II)-Sephadex as described previously. Approximately one third of amino nitrogen was in the form of di- and tripeptides, while oligopeptides of chain length greater than four amino acid residues comprised $62 \%$ of the milk protein hydrolysate (see Table III).

\section{TECHNIQUE OF ADMINISTRATION}

Patients 6 and 7 had surgically fashioned jejunostomies. The remainder were intubated with a fine bore $(2.1 \mathrm{~mm}$ od, $1.37 \mathrm{~mm}$ id) nasogastric feeding tube (Corpak Co, Wheeling, Il, USA). The aim was to administer daily at least $2 \cdot 251$ 
$(10.8 \mathrm{gN})$ of enteral diet, by continuous $24 \mathrm{~h}$ infusion under gravity control from 1.51 plastic bags, at full strength from the outset of feeding. 'Starter' regimes were not used in any of the patients.'

\section{GASTROINTESTINAL TOLERANCE}

Daily assessment of each patient for gastrointestinal side effects was made and recorded from direct questioning using a standard questionnaire. ${ }^{10}$

INTAKE OF ENTERAL DIET, NITROGEN ABSORPTION AND BALANCE

Actual daily intake of enteral diet was recorded prospectively for each patient by a member of the Nutrition Support Team. Continuous daily stool (or stomal) and urine collections were made on the wards by the nursing staff into 51 tins and 2.51 polyethylene bottles respectively and then weighed. Total faecal and urinary nitrogen for the last five days of each study period were determined on aliquots, which if not analysed immediately had been stored at $-20^{\circ} \mathrm{C}$, by chemiluminescence according to techniques developed in our laboratory. " Corresponding mean daily net nitrogen absorption (derived from the difference between nitrogen intake and stool losses) and nitrogen balance were then calculated for each patient.

\section{STATISTICAL ANALYSIS}

Significance of difference between the enteral diets with regard to stool data, nitrogen absorption and balance were tested by the nonparametric Wilcoxon's rank-sum test for matched pairs.

\section{Results}

COMPLETION OF FEEDING AND GASTROINTESTINAL SIDE EFFECTS

Seven of the 12 patients were randomised to enteral nutrition starting with the peptide containing enteral diet, and five with the polymeric diet. Two patients did not complete the study because of gastrointestinal side effects. These were patient 2 , with resolved pancreatitis and partial gastrectomy (on the whole protein diet), and patient 7 , with periduodenal abscess (on the peptide diet). Both patients developed diarrhoea and abdominal bloating. Only one other patient developed gastrointestinal symptoms. This was patient 9, with jejunal diverticula, who, although tolerating the peptide diet well, developed diarrhoea while on the whole protein diet (second diet), but was able to complete the study.

STOOL WET WEIGHT AND STOOL NITROGEN Daily stool or stomal effluent wet weights, with nitrogen contents, for patients who completed the study are shown in Table IV. There was considerable between patient variation in total output and nitrogen content. The majority of between diet (paired) data were close in value.
Exceptions were patient 9 who had jejunal diverticula, patient 10 with gastrointestinal amyloidosis and patient 12 with ileocolonic Crohn's disease and a colostomy. In these patients, enteral feeding with the peptide diet was associated with lower stool (or ostomy) wet weight and nitrogen content, compared with the whole protein diet. When all data were considered, there was no statistically significant difference in either stool weight or stool nitrogen loss between the two diets for patients who completed the study.

\section{NITROGEN ABSORPTION AND NITROGEN BALANCE (TABLE V)}

There was no significant difference in nutrient intake, either between patient or between diet, and the mean intake of nitrogen for the peptide and whole protein diets compared well at $\mathbf{9 . 8}$ (SEM) (0.3) and 9.4 (0.3) $\mathrm{g}$ respectively. There was also no significant difference in either net nitrogen absorption or nitrogen balance between the two test diets, and both mean nitrogen balances were positive with values of $+1 \cdot 0(1 \cdot 3)$ $v+0.6(1.4) \mathrm{g}$ nitrogen/d for peptide and whole protein based diets respectively. The data also show that both peptide and whole protein nitrogen sources were mostly very well absorbed at 91 (2)\% $v 89(2) \%$ for peptide and whole protein diets. Again exceptions were patients 9, 10, and 12, who had extensive small bowel mucosal defects, and in whom noticeably better nitrogen absorption and balance occurred when the exogenous nitrogen source was peptides rather than whole protein.

There was no significant difference in mean daily urinary total nitrogen excretion (and, therefore, nitrogen retention) with respect to nitrogen source.

\section{Discussion}

The aim of this controlled clinical trial was to investigate whether patients considered to have moderately impaired gastrointestinal function should be prescribed a predigested enteral diet, rather than one containing a whole protein based nitrogen source. It was hoped that in addition it might be possible to identify categories of patient in whom the prescribing of a predigested enteral diet was indicated. When interpreting the present data, it is important to remember that the experimental design was based on the study of a clinically heterogenous group of patients. These had widely varying primary diagnoses and underlying gastrointestinal defects, and we considered that the correct method of comparing the nutritional efficacy of the two enteral diets was to perform a randomised crossover double blind

TABLE III Peptide chain length distribution in the partial enzymic hydrolysate of milk proteins

\begin{tabular}{lc}
\hline & $\%$ Alpha \\
& amino nitrogen \\
\hline Free amino acids & 2 \\
Dipeptides & 12 \\
Tripeptides & 22 \\
Tetrapeptides & 2 \\
> Tetrapeptides & 62 \\
\hline
\end{tabular}


TABLE IV Stool wet weight and nitrogen content on days 3 to $7(g / d)$

\begin{tabular}{|c|c|c|c|c|}
\hline \multirow[b]{2}{*}{ Patient } & \multicolumn{2}{|c|}{ Peptide diet } & \multicolumn{2}{|c|}{ Whole protein diet } \\
\hline & Weight & $N$ & Weight & $N$ \\
\hline 1 & 52 & 0.6 & 49 & 0.4 \\
\hline 3 & 61 & 0.8 & 89 & 1.4 \\
\hline 4 & 102 & 0.7 & 92 & 0.8 \\
\hline 5 & 45 & 0.3 & 22 & 0.3 \\
\hline 6 & 74 & $1 \cdot 2$ & 26 & 0.5 \\
\hline 8 & 541 & $2 \cdot 6$ & 379 & $2 \cdot 1$ \\
\hline 9 & 19 & $0 \cdot 1$ & 111 & $1 \cdot 3$ \\
\hline 10 & 23 & 0.3 & 118 & 0.9 \\
\hline 11 & 141 & $2 \cdot 0$ & 117 & 1.4 \\
\hline 12 & 42 & 0.6 & 106 & $1 \cdot 1$ \\
\hline Mean (SEM) & $110(49)^{\star}$ & $0.9(0.2)^{\star}$ & $111(32)^{\star}$ & $1 \cdot 0(0 \cdot 2)^{\star}$ \\
\hline
\end{tabular}

*ns.

study, in which each patient acted as their own control.

Both enteral diets were equally well tolerated in that only two patients were withdrawn from the study on account of gastrointestinal side effects (diarrhoea), one each on commencing the peptide and whole protein containing enteral diets. In addition, patient 9 , with jejunal diverticulosis, was relatively intolerant of the polymeric diet. It must be born in mind, however, that the two test enteral diets differed in fat content and composition, as well as nitrogen formulation, and this aspect could have affected gastrointestinal tolerance. Positive nitrogen balance was achieved with both diets in seven of 10 patients, with a mean intake of approximately $10 \mathrm{~g}$ nitrogen/d; and when considering all patients, there was no nutritional advantage from feeding the peptide based nitrogen source. Closer examination of the data, however, revealed that in three patients, 9,10 , and 12 , better net nitrogen absorption and nitrogen balance occurred with the peptide, rather than the whole protein, based enteral diet (Table V). Before discussing this apparent nutritional benefit from feeding oligopeptides in these patients, consideration should be given to three factors in the design of the present study.

The first is the period of time allowed for the study periods. Balance studies in healthy volunteers have revealed the presence of time dependent adaptations of the gastrointestinal tract to liquid defined formula diets, after normal solid food. ${ }^{12}{ }^{13}$ Gastrointestinal adaptation appears to take longer than seven days. Long study periods are not practical for most hospital patients and the randomised crossover design of the present study, where each patient acted as their own control, should have allowed for any physiological variables. Interpretation of the present data, however, must be seen in the context of a short term study.

Second, it is possible that the present results were prejudiced by the nature of the predigested nitrogen source tested. From recent in vivo jejunal perfusion studies in our laboratory, it has been observed that mucosal brush border hydrolysis is rate limiting with respect to nitrogen uptake from oligopeptides; and that subtle increases in peptide chain length from 2-3 to 3-5 amino acid residues have a significantly deleterious effect on $\alpha$-amino acid nitrogen absorption. ${ }^{8}$ These data therefore indicate that in order to promote maximum absorption of $\alpha$-amino acid nitrogen per unit length of intestine, consideration should be given to using a predigested dietary nitrogen preparation that contains a preponderance of di- and tripeptides. In the present study, small peptides of 2 to 3 amino acid residue comprised only about one third of dietary nitrogen supplied by the peptide based diet (Table III)

Further examination of the data indicates, however, that for the majority of patients, it is highly unlikely that any possible nutritional advantage from using the partial enzymic hydrolysate could have been precluded by the peptide chain length profile. With both enteral diets, mean net nitrogen absorption and total stool nitrogen were approximately $90 \%$ and $1 \mathrm{~g}$ nitrogen/d respectively (Tables IV and V). The latter value is no greater than that found for endogenous nitrogen losses alone from the human small bowel in healthy subjects. ${ }^{1+}$ Thus, even allowing for subsequent colonic salvage of nitrogen through fermentation to ammonia, ${ }^{15}$ the present results indicate that, in most patients, both nitrogen sources were very well absorbed in the small bowel.

The last issue is whether the extent of gastrointestinal disease or dysfunction present in the patients studied, would have been likely to have measurably impaired the assimilation of whole protein. The reserve capacity of gastrointestinal function for nutrient assimilation is large. Studies in normal subjects have shown that the bulk of ingested protein appears to be absorbed in the proximal jejunum. ${ }^{16}$ Also, it appears that in the presence of normal gastrointestinal function, up to $90 \%$ impairment of exocrine pancreatic function has to occur before luminal hydrolysis becomes rate limiting to the assimila-

TABLE $\mathrm{V}$ Net nitrogen absorption and nitrogen balance on days 3 to 7 ( $\mathrm{g}$ nitrogen/d)

\begin{tabular}{|c|c|c|c|c|c|c|c|c|}
\hline \multirow[b]{2}{*}{ Patient } & \multicolumn{2}{|l|}{ Peptide diet } & \multirow{2}{*}{$\begin{array}{l}\text { Urinary } \\
\text { excretion }\end{array}$} & \multirow[b]{2}{*}{ Balance } & \multicolumn{2}{|c|}{ Whole protein diet } & \multirow{2}{*}{$\begin{array}{l}\text { Urinary } \\
\text { excretion }\end{array}$} & \multirow[b]{2}{*}{ Balance } \\
\hline & Intake & \% Absorption & & & Intake & $\%$ Absorption & & \\
\hline 1 & $9 \cdot 7$ & 94 & $5 \cdot 0$ & $+4 \cdot 1$ & $9 \cdot 6$ & 96 & $5 \cdot 8$ & $+3 \cdot 4$ \\
\hline 3 & 8.8 & 90 & 3.8 & $+4 \cdot 2$ & $10 \cdot 4$ & 87 & $4 \cdot 0$ & $\begin{array}{l}+5.0 \\
\end{array}$ \\
\hline 4 & $9 \cdot 7$ & 93 & $5 \cdot 4$ & +3.6 & 9.6 & 93 & 3.0 & $\begin{array}{l}+5.8 \\
\end{array}$ \\
\hline 5 & 10.9 & 97 & 8.0 & +2.6 & $10 \cdot 8$ & 97 & $7 \cdot 4$ & $+3 \cdot 1$ \\
\hline 6 & 8.9 & 87 & $14 \cdot 5$ & -6.8 & $7 \cdot 3$ & 93 & $11 \cdot 6$ & -4.8 \\
\hline 8 & 10.9 & 76 & 5.0 & $\begin{array}{r}+3 \cdot 3 \\
\end{array}$ & $10 \cdot 8$ & 80 & 5.8 & +2.9 \\
\hline 9 & $9 \cdot 2$ & 99 & $5 \cdot 7$ & +3.4 & $8 \cdot 4$ & 84 & $5 \cdot 3$ & +1.8 \\
\hline 10 & 8.8 & 96 & $5 \cdot 4$ & $+3 \cdot 1$ & $8 \cdot 4$ & 89 & $7 \cdot 0$ & +0.5 \\
\hline 11 & 10.9 & 82 & $12 \cdot 4$ & -3.5 & $9 \cdot 3$ & 85 & 13.5 & -5.6 \\
\hline 12 & 10.7 & & 13.6 & -3.5 & 9.6 & 88 & $14 \cdot 7$ & $-6 \cdot 2$ \\
\hline Mean (SEM) & $9 \cdot 8(1 \cdot 3)^{\star}$ & $91(2)^{\star}$ & $7.9(1 \cdot 3)^{\star}$ & $+1 \cdot 0(1 \cdot 3)^{\star}$ & $9 \cdot 4(0 \cdot 3)^{\star}$ & $89(2)^{\star}$ & $7 \cdot 8(1 \cdot 3)^{\star}$ & $+0.6(1.4)^{\star}$ \\
\hline
\end{tabular}


tion of amino acids and peptides from whole protein. ${ }^{17}$ The present data indicate that both forms of exogenous nitrogen were very well absorbed $(>87 \%)$ in the presence of either pancreatic disease (or excision) alone, or with partial gastrectomy where loss of control of gastric emptying may impair digestion. ${ }^{18}$ The finding of good absorption of both peptide (90\%) and whole protein $(87 \%)$ sources of nitrogen in patient 3, who had undergone a Whipple's pancreatectomy, was at first sight surprising. Steinhart et $a l^{19}$ have also shown significant absorption (53 (12)\%) of intact protein in five pancreatectomised patients. The presumptive mechanism involved in the assimilation of whole protein, in the absence of luminal pancreatic proteolytic enzyme activity, is the hydrolysis of large polypeptides by brush border associated endopeptide hydrolases, recently characterised in the rat small intestine. ${ }^{20}$

The present results, therefore, continue to highlight the magnitude of the functional reserve assimilatory capacity of the human small intestine. In keeping with our data, showing largely satisfactory assimilation of whole protein in the face of impaired gastrointestinal function, are the results of two recent studies. The first, ${ }^{21}$ carried out in colectomised patients with or without small bowel resection, showed that there was no nutritional benefit in nasogastric feeding with an enteral diet containing peptides (chain length unspecified), compared with whole protein. In fact, significantly better nitrogen absorption from the whole protein based diet was documented in both groups of patients, with a mean of 75 (SEM) (1)\% absorption in patients with $>100 \mathrm{~cm}$ of ileal resection. In the second study, ${ }^{22}$ the same group of workers were also unable to show, in early postoperative patients fed intraduodenally, any difference in nitrogen balance between peptide and whole protein containing enteral diets.

Thus, when considered as a group, there appeared to be no indication for prescribing an enteral diet with a predigested nitrogen source to patients perceived to have moderately impaired gastrointestinal function. It did emerge, however, that patients 9,10 , and 12 , whose net absorption of nitrogen was relatively better from the peptide based enteral diet, may represent a clinically identifiable sub group of patients with clinically significant malabsorption. In these patients, who had small bowel disease (jejunal diverticulosis, amyloidosis and ileocolonic Crohn's disease respectively (Table I)), intestinal mucosal absorptive reserve capacity appears to have been sufficiently impaired for the oligopeptide nitrogen source to have had a nutritional advantage over whole protein.

In conclusion, these results indicate that the prescribing of enteral diets containing a pre- digested nitrogen source, in order to achieve positive nitrogen balance, is not indicated in the majority of patients with moderately impaired gastrointestinal function. There appears to be a subgroup of patients, characterised by specific small bowel disease, however, who may require short chain peptides, preferably di- and tripeptides, rather than whole protein for optimum nitrogen absorption.

1 Payne-James JJ, de Gara CJ, Grimble GK, Doherty J, Rana S, Cribb R, et al. Nutritional Support in Hospitals in the United Kingdom: National Survey 1988. Health Trends 1990; 1: 9-13.

2 Jones BJM, Lees R, Andrews J, Frost P, Silk DBA. Comparison of an elemental and polymeric enteral diet in patients with normal gastrointestinal function. Gut $1883 ; 24$ : 78-84.

3 Rees RGP, Cooper TM, Beetham R, Frost PG, Silk DBA Influence of energy and nitrogen contents of enteral diets on nitrogen balance: a double blind prospective controlled clinical trial. Gut 1989; 30: 123-9.

4 Silk DBA. Towards the optimization of enteral nutrition. Clin Nutr 1987; 6: 61-74.

5 Silk DBA, Fairclough PD, Clark ML, Hegarty JE, Marrs TC, Addison JM, et al. Uses of a peptide rather than a free amino acid nitrogen source in chemically defined elemental diets. F Parent Ent Nutr 1980; 4: 548-53.

6 Jelliffe DB. Assessment of the nutritional status of the community. Geneva: World Health Organisation, 1966.

7 Bond JH, Levitt MD. Use of breath hydrogen $\left(\mathrm{H}_{2}\right)$ in the study of carbohydrate absorption. Am $\mathcal{F}$ Dig Dis 1977; 22: $379-82$.

8 Grimble GK, Rees RG, Keohane PP, Cartwright T, Desreumaux M, Silk DBA. Effect of peptide chain length on absorption of egg protein hydrolysates in the normal human jejunum. Gastroenterology 1987; 92: 136-42.

9 Keohane PP, Attrill H, Love M, Frost P, Silk DBA. Relation between osmolality of diet and gastrointestinal side effects in enteral nutrition. BMF 1984; 288: 678-80.

10 Keohane PP, Attrill H, Jones BJM. Brown I, Frost P, Silk DBA. The roles of lactose and Clostridium difficile in the pathogenesis of enteral feeding associated diarrhoea. Clin Nutr 1983; 1: 259-64.

11 Grimble GK, West MFE, Acuti ABC, et al. Assessment of an automated chemiluminescence nitrogen analyser for use in clinical nutrition. F Parenter Enteral Nutr 1988; 12: 100-6.

12 Duke JH, Amen RJ, Beigler MA, Spiller GA, Saperstein S. Physiological effects of defined formula diets based on hydrolysates and intact protein. Z Ernahrungswiss 1977 (suppl 20): 38-47.

13 Spiller GA, Beigler MA. Time-dependent gastrointestina adaptation of human subjects and non-human primates to liquid defined formula diets. $Z$ Ernahrungswiss 1977 (supp 20): 48-57.

14 Chacko A, Cummings JH. Nitrogen losses from the human small bowel: obligatory losses and the effect of physical form of food. Gut 1988; 29: 809-15.

15 Gibson JA, Sladen GE, Dawson AM. Protein absorption and ammonia production: the effects of dietary protein and removal of the colon. Br 7 Nutr 1976; 35:61-5.

16 Borgström D, Dahlqvist A, Lundh G, Sjövall J. Studies of intestinal digestion and absorption in the human. $\mathcal{f}$ Clin Invest 1957; 36: 1521-36.

17 Crane CW. Studies on the absorption of ${ }^{15} \mathrm{~N}$ labelled yeast protein in normal subjects and patients with malabsorption. In: Munro HN, ed. The role of the gastrointestinal tract in protein metabolism. Philadelphia: FA Davis, 1964: 333-47.

18 Dozois RR, Kelly KA, Code CF. Effect of distal antrectomy on gastric emptying. Gastroenterology 1971; 61: 675-81.

19 Steinhardt HJ, Wolf A, Jakober B, Schmuelling RM, Lange $\mathrm{K}$, Brandl $\mathrm{M}$, et al. Nitrogen absorption in pancreatectomised patients: Protein versus protein hydrolysate as substrate. F Lab Clin Med 1989; 113: 162-7.

20 Song IS, Yoshioka M, Erickson RH, Miura S, Guan D, Kim YS. Identification and characterization of brush-border membrane-bound neutral metalloendopeptidases from small intestine. Gastroenterology 1986; 91: 1234-42.

21 Andersson H, Bosaeus I, Ellegand L, Hallgren B, Hulton L, Magnusson $\mathrm{O}$. Comparison of an elemental and two polymeric diets in colectomized patients with or without intestinal resection. Clin Nutr 1984; 3: 183-9.

22 Andersson H, Hulton L, Magnusson O, Sandstrom B. Energy and mineral utilization from a peptide-based elemental diet given to ileostomists in the early post-operative course f Parenter Enteral Nutr 1984; 8: 497-500. 